\title{
CLINICAL EVALUATION OF NEBULISED BUDESONIDE IN ACUTE EXACERBATION OF CHRONIC OBSTRUCTIVE PULMONARY DISEASE- A RANDOMISED STUDY
}

\author{
Gajanan S. Gaude1, Santosh Nemagouda²
}

1 Professor and HOD, Department of Pulmonary Medicine, J. N. Medical College, Belgaum.

${ }^{2}$ Associate Professor, Department of Pulmonary Medicine, Shri B. M. Patil Medical College, Vijayapura.

ABSTRACT
BACKGROUND
Exacerbations in chronic obstructive pulmonary disease is common and frequent in nature. The present study was done to
evaluate the clinical efficacy of nebulised budesonide over parenteral/oral steroids in patients with acute exacerbations of COPD.

\section{MATERIALS AND METHODS}

A randomised controlled study was conducted in a tertiary care teaching hospital. A total of 125 patients with acute exacerbations due to COPD were included in the study. The patients were randomised into study and control groups. The study group patients received inhaled budesonide along with the standard treatment for 5 days, while the control group received standard treatment for acute exacerbation of COPD. The primary outcome variables studied for the treatment efficacy were change in post bronchodilator $\mathrm{FEV}_{1}, \mathrm{FVC}, \mathrm{FEV} / \mathrm{FVC}$, PEFR. Secondary end points included the changes in dyspnoea score $\left(\mathrm{MMRC}^{\mathrm{grade}} \mathrm{SPO}_{2}\right.$ and SGRQ score).

\section{RESULTS}

A total of 125 patients were finally assessed. Sixty five patients belonged to study group and 60 in the control group. Baseline characteristics were similar and well matched in both the groups. Mean age was $64.20 \pm 9.11$ years while in control group it was $62.40 \pm 11.31$ years. There were no improvements in the lung functions $\left(\mathrm{FEV}_{1}, \mathrm{FVC}, \mathrm{FEV}_{1} / \mathrm{FVC}\right.$, PEFR) at the end of 5 days of nebulised budesonide as compared to the standard therapy. As far as secondary outcome is concerned, it was observed that patients in study group showed better improvement in health related quality of life (HRQL) score as compared to control group at day $5(\mathrm{p}<0.01)$. Duration of hospitalisation also was lesser in the study group as compared to the control group. No serious adverse effects were observed during the course of the study.

\section{CONCLUSION}

Overall with the nebulised budesonide for the AECOPD, there was not much improvement in the lung functions, but there was improvement in the quality of life and the duration of hospitalisation in the study group. These findings should be confirmed by conducting a larger population based clinical study.

\section{KEYWORDS}

COPD, Acute Exacerbations, AECOPD, Nebulised Budesonide, Lung Functions, FEV 1 , PEFR.

HOW TO CITE THIS ARTICLE: Gaude G, Nemagouda S. Clinical evaluation of nebulised budesonide in acute exacerbation of chronic obstructive pulmonary disease- A randomised study. J. Evolution Med. Dent. Sci. 2017;6(92):6561-6565, DOI: $10.14260 /$ jemds/2017/1422

\section{BACKGROUND}

Chronic obstructive pulmonary disease (COPD) is a leading cause of morbidity and mortality worldwide and results in an economic and social burden that is both substantial and increasing. COPD is the $4^{\text {th }}$ leading cause of death in the United States of America (USA) and Europe. ${ }^{1}$ Currently, COPD is a costlier disease to treat than asthma and depending on country, $50 \%-75 \%$ of the costs are for services associated with exacerbation. Tobacco smoke is by far the most important risk factor for COPD worldwide. An exacerbation is defined as an event in the natural course of the disease characterised by change in the patients

'Financial or Other Competing Interest': None.

Submission 10-07-2017, Peer Review 16-11-2017,

Acceptance 22-11-2017, Published 04-12-2017.

Corresponding Author:

Dr. Gajanan S. Gaude,

Professor and HOD,

Department of Pulmonary Medicine,

J. N. Medical College,

Belgaum-590010.

E-mail: gsgaude922@gmail.com

DOI: $10.14260 /$ jemds $/ 2017 / 1422$

(c) $(7)$ baseline dyspnoea, cough and/or, sputum that is beyond normal day-to-day variation, is acute in onset and may warrant a change in regular medication in a patient with COPD. ${ }^{2}$ Systemic corticosteroids are used to treat acute exacerbation of COPD. This common clinical practice has been endorsed by various international guidelines. Compared with placebo, systemic corticosteroids accelerate the recovery of expiratory flow rates and reduce the length of hospital stays in patients with acute exacerbation of chronic obstructive pulmonary disease (AECOPD) receiving standard medical treatment with bronchodilators, antibiotics and oxygen. Despite proof of efficacy, some concerns remain about using systemic corticosteroids to treat all patients with AECOPD. This is mainly because the short-term advantages of corticosteroids may be outweighed by the occurrence of adverse effects such as hyperglycaemia, myopathy and osteoporosis. $^{3}$ It has recently been reported that suppression of the adrenal response is common after short term, high dose corticosteroid treatment. 4

In this context, the possibility of treating patients with AECOPD with inhaled corticosteroids, having less systemic adverse effects is of particular interest. Inhaled corticosteroids have a high level of topical anti-inflammatory 
activity and a low level of systemic activity. ${ }^{5}$ Preliminary data have demonstrated that nebulised budesonide to be as efficacious as parenteral corticosteroids in the treatment of acute severe asthma. ${ }^{6}$ Nebulised budesonide may also be sufficiently efficacious in the management of acute exacerbation of COPD, but only limited number of studies are available which have demonstrated that it might be an alternative agent in AECOPD, instead of the parenteral steroids. Hence, the present study was undertaken to know the clinical efficacy of nebulised budesonide with parenteral/oral steroids in patients with AECOPD.

\section{MATERIALS AND METHODS}

The present study was conducted in the Department of Pulmonary Medicine, KLES Dr. Prabhakar Kore Hospital and Medical Research Centre, Belgaum on adult patients diagnosed to have AECOPD. A total of 130 patients diagnosed to have AECOPD in one-year period were included in the study- 65 patients each in the control and study group.

\section{Inclusion Criteria}

Patients with AECOPD

An exacerbation is defined as an event in the natural course of the disease characterised by change in the patients baseline dyspnoea, cough and/or, sputum that is beyond normal day-to-day variation, is acute in onset and may warrant a change in regular medication in a patient with COPD.

\section{Exclusion Criteria}

Patients with asthma, allergic rhinitis and atopy, specific cause for exacerbation such as pneumonia, pneumothorax, heart failure, etc., and patients with a risk of imminent respiratory failure requiring mechanical ventilator or direct admission to the ICU

\section{Procedure}

The study was approved by the Ethical and Research Committee of Jawaharlal Nehru Medical College, Belgaum. Patients fulfilling the inclusion criteria were included in the study. The selected patients were briefed about the nature of study and written informed consent was obtained. This was a hospital-based randomised study in patients with AECOPD done over a period of one year. These patients were grouped into two groups randomly consisting of 65 patients each in the control and study group. Randomisation was done by the lottery method for all the consecutive patients. The data like demography, history were recorded on predesigned and pretested proforma.

Group 1 (control group) received parenteral/oral steroids (IV hydrocortisone $200 \mathrm{mg}$ t.d.s./40 $\mathrm{mg}$ of oral prednisolone) along with standard treatment that is; Salbutamol $(2.5 \mathrm{mg})+$ Ipratropium bromide $(500 \mu \mathrm{g})$ nebulisation every sixth hourly, supplemental oxygen inhalation, parenteral antibiotics, parenteral Deriphyllin and supportive therapy.

Group 2 (Study group) received budesonide nebulisation ( $2 \mathrm{mg}$ diluted in $4 \mathrm{~mL}$ of normal saline every sixth hourly) along with standard treatment.

The patients were assessed for following parameters at different intervals: (i) Spirometry was carried out at baseline, 24 hours, 72 hours and on fifth day according to ATS standards3; (ii) Dyspnoea was assessed according to the
Modified Medical Research Council (MMRC) Grade; (iii) PEFR and $\mathrm{SPO}_{2}$ were assessed at baseline, 24 hours, 72 hours and on fifth day; (iv) St. George Respiratory Questionnaire (SGRQ) was assessed at baseline, 24 hours and on fifth day.

\section{Outcome Variables}

The primary outcome variables studied for the treatment efficacy were change in post bronchodilator $\mathrm{FEV}_{1}, \mathrm{FVC}$, $\mathrm{FEV}_{1} / \mathrm{FVC}$, PEFR. Secondary end points included the changes in dyspnoea score (MMRC grade, $\mathrm{SPO}_{2}$ and SGRQ score).

An adverse event is defined as any event reported by the patients from study entry to day 10 or discharge. Serious adverse events included life-threatening events and events resulting in prolongation of hospitalisation. Study discontinuation due to adverse events, including COPD deterioration or relapse was also monitored.

Deterioration of AECOPD while patients under study were defined as the need for treatment intensification according to the treating doctor, the development of confusion, lethargy, acute respiratory acidosis or need for mechanical ventilatory assistance.

Safety of study medication was assessed by monitoring occurrence of any adverse events during the acute and the followup phase of the study. Complete blood cell count including eosinophils obtained at admission.

\section{Monitoring of Patients \\ Immediate (From Admission to 72 Hours of Hospitalisation)}

Spirometry (FEV $1, F V C, F_{1}$, FVC) at baseline, 24 hours, 48 hours and 72 hours; PEFR and $\mathrm{SPO}_{2}$ at baseline, 24 hours, 48 hours and 72 hours; Dyspnoea (MMRC grade) was assessed at baseline, 24 hours, 48 hours and 72 hours; and SGRQ score at baseline and 24 hours.

\section{After 72 Hours till Fifth Day and Discharge}

Spirometry, PEFR, Dyspnoea grade and SGRQ score was monitored. The initial treatment was not changed for 10 days if the hospitalisation period exceeded 10 days. Both forms of corticosteroid preparations were tapered or discontinued according to the need. After discharge, all patients were advised combined form of inhaled salbutamol with ipratropium (transcaps q.i.d.), long acting $\beta_{2}$ agonist with inhaled corticosteroids, and methylprednisolone $16 \mathrm{mg}$ twice daily for seven days orally.

In this study, the criteria to assess relapse of exacerbation of COPD was the number of unscheduled visits to any medical units due to increased symptoms of COPD requiring hospitalisation within one month after discharge.

\section{Statistical Analysis}

For the various parameters mean and standard deviation (S.D.) were calculated. From baseline to three different time points comparison was made using student's paired ' $t$ ' test. The comparison of the parameters in the study group and the control was done using student's unpaired ' $t$ ' test. Chi-square test was used for comparing other characters between two groups. Fisher's Exact test was used to find out the level of significance between the intervals in the groups. A 'p' value of less than 0.05 was considered as statistically significant. 


\section{RESULTS}

A total of 130 patients were included in this study in 1:1 ratio. Five patients were excluded from the final analysis as they deteriorated during the study period and required intensification of the treatment. Thus, finally 125 patients were analysed- 63 patients in study group and 62 patients in control group. The mean age of the patients in study group was $64.20 \pm 9.11$ years while in control group it was $62.40 \pm$ 11.31 years. The duration of disease in the control group was $6.60 \pm 4.80$ years while it was $6.90 \pm 3.30$ in the study group (Table 1). Overall male to female ratio was $3: 1$. In this study, majority of the patients belonged to age group of 51 to 60 years and 61 to 70 years.

The baseline $\mathrm{FEV}_{1}$ was $0.45 \pm 0.11 \mathrm{~L} / \mathrm{Sec}$ in the study group and it was $0.51 \pm 0.14 \mathrm{~L} / \mathrm{Sec}$ in the control group (Table 2). The mean improvement in $\mathrm{FEV}_{1}$ after 24 hours, 72 hours and at $5^{\text {th }}$ day was $0.53 \pm 0.15 \mathrm{~L} / \mathrm{Sec}, 0.64 \pm 0.18 \mathrm{~L} / \mathrm{Sec}$ and $0.82 \pm 0.19 \mathrm{~L} / \mathrm{Sec}$ in study group, while it was $0.55 \pm 0.15$ $\mathrm{L} / \mathrm{Sec}, 0.69 \pm 0.15 \mathrm{~L} / \mathrm{Sec}$ and $0.80 \pm 0.16 \mathrm{~L} / \mathrm{Sec}$ in control group respectively. It was observed that there was no statistical significance observed in $\mathrm{FEV}_{1}$ improvement between the two groups at different intervals of the study period (Table 3). Baseline FVC observed in the study and the control group was $0.88 \pm 0.19 \mathrm{~L} / \mathrm{Sec}$ and $0.99 \pm 0.30 \mathrm{~L} / \mathrm{Sec}$ respectively. Applying ANOVA method, it was also observed that there was no statistical significance observed in FVC improvement between the two groups (Table 4). Similarly, there was no difference in $\mathrm{FEV}_{1} / \mathrm{FVC}$ percent ratio between the study group and the control group at different time intervals after the use of the medications.

As far as PEFR is concerned, the baseline PEFR in both study and control groups were $141 \pm 69.46 \mathrm{~L} / \mathrm{M}$ and $139 \pm$ $91.15 \mathrm{~L} / \mathrm{M}$ respectively. When compared at different intervals, there was no statistically significant difference in PEFR values between the study group and the control group. The baseline oxygen saturation in both control and study group were $97 \% \pm 1.65 \%$ and $97 \% \pm 1.67 \%$ respectively. However, when compared at different intervals that is 24 hours, 72 hours and at fifth day, there was no statistical significant difference between the study group and the control group ( $\mathrm{p}>0.05)$.

Overall MMRC dyspnoea grade was 4 in both study and control groups at baseline. There was improvement in dyspnoea scale by one point in both the study group and the control group after 5 days of therapy (Table 5). Baseline SGRQ scores observed in study and control group were 88.76 \pm 5.32 and $86.43 \pm 4.75$ respectively. SGRQ score improvement after 24 hours and at $5^{\text {th }}$ day in study group was $82.55 \pm 5.35$ and $68.95 \pm 6.75$ while it was $82.36 \pm 4.81$ and $70.80 \pm 7.09$ in control group respectively. Patients in study group showed better improvement in health related quality of life (HRQL) score as compared to control group at day $5(\mathrm{p}<0.01)$. In control group, HRQL score improved among $83.3 \%$ patients and remained same in $13.3 \%$ patients. In study group, $89.3 \%$ patients had improved HRQL score and while the score remained same among $10.7 \%$ patients (Table 6).

A total of 58 patients (89.2\%) had total hospitalisation of less than 10 days in the study group. Twelve patients (20\%) had more than 12 days of hospitalisation in the control group, while it was $10.8 \%$ in the study group. Thus, it was observed more number of patients were discharged early in the study group as compared to control group (Table 7). A total of five patients $(8.3 \%)$ in the control group were readmitted with relapse of AECOPD within 30 days of discharge from hospital. In the study group, two patients (3.0\%) were readmitted for the relapse of exacerbation during the study period.

\begin{tabular}{|c|c|c|c|}
\hline $\begin{array}{c}\text { Demographic } \\
\text { Characteristics }\end{array}$ & $\begin{array}{c}\text { Control Group } \\
\text { (n=65) }\end{array}$ & $\begin{array}{c}\text { Study Group } \\
\text { (n=65) }\end{array}$ & $\begin{array}{c}\text { p value } \\
\text { Mean }\end{array}$ \\
\cline { 2 - 3 } & Mean \pm SD & Mean \pm SD & \\
\hline Age (Years) & $62.40 \pm 11.31$ & $64.20 \pm 9.11$ & 0.315 \\
\hline Duration (Years) & $6.60 \pm 4.80$ & $6.90 \pm 3.30$ & 0.765 \\
\hline Pack years & $10.40 \pm 4.80$ & $8.60 \pm 4.50$ & 0.019 \\
\hline Hb\% (g\%) & $11.50 \pm 1.55$ & $12.03 \pm 1.24$ & 0.091 \\
\hline TLC (/mm³) & $\begin{array}{c}13624.00 \pm \\
1189.00\end{array}$ & $\begin{array}{c}10589.00 \pm \\
5513.00\end{array}$ & 0.062 \\
\hline B Urea (mg/dL) & $47.00 \pm 19.40$ & $45.00 \pm 19.15$ & 0.700 \\
\hline $\begin{array}{c}\text { Sr. Creatinine } \\
\text { (mg/dL) }\end{array}$ & $0.89 \pm 0.31$ & $0.83 \pm 0.41$ & 0.319 \\
\hline \multicolumn{2}{|c|}{ Table 1. Baseline Characteristics of the Patients } \\
\hline
\end{tabular}

Table 1. Baseline Characteristics of the Patients

\begin{tabular}{|c|c|c|c|}
\hline \multicolumn{2}{|c|}{ Variables } & \multirow{2}{*}{$\begin{array}{c}\begin{array}{c}\text { Control Group } \\
(\mathrm{n}=62) \\
\text { S.D. }\end{array} \\
0.51 \pm 0.14\end{array}$} & \multirow{2}{*}{$\begin{array}{c}\begin{array}{c}\text { Study Group } \\
(\mathrm{n}=63) \text { Mean } \pm \\
\text { S.D. }\end{array} \\
0.45 \pm 0.11\end{array}$} \\
\hline \multirow{4}{*}{$\begin{array}{c}\mathrm{FEV}_{1} \\
(\mathrm{~L} / \mathrm{sec})\end{array}$} & Baseline & & \\
\hline & 24 hours & $0.55 \pm 0.15$ & $0.53 \pm 0.15$ \\
\hline & 72 hours & $0.69 \pm 0.15$ & $0.64 \pm 0.17$ \\
\hline & $5^{\text {th }}$ day & $0.80 \pm 0.16$ & $0.82 \pm 0.19$ \\
\hline \multirow{4}{*}{$\begin{array}{c}\text { FVC } \\
(\mathrm{L} / \mathrm{sec})\end{array}$} & Baseline & $0.99 \pm 0.33$ & $0.88 \pm 0.14$ \\
\hline & 24 hours & $1.06 \pm 0.31$ & $0.99 \pm 0.18$ \\
\hline & 72 hours & $1.24 \pm 0.33$ & $1.13 \pm 0.22$ \\
\hline & $5^{\text {th }}$ day & $1.45 \pm 0.37$ & $1.36 \pm 0.26$ \\
\hline \multirow{4}{*}{$\begin{array}{l}\mathrm{FEV}_{1} / \\
\mathrm{FVC} \%\end{array}$} & Baseline & $51.79 \pm 12.38$ & $50.66 \pm 7.66$ \\
\hline & 24 hours & $52.46 \pm 12.96$ & $53.05 \pm 7.40$ \\
\hline & 72 hours & $56.29 \pm 11.33$ & $55.76 \pm 9.97$ \\
\hline & $5^{\text {th }}$ day & $61.25 \pm 10.27$ & $59.21 \pm 9.56$ \\
\hline \multirow{4}{*}{$\begin{array}{c}\text { PEFR } \\
\text { (L/min.) }\end{array}$} & Baseline & $139.00 \pm 91.15$ & $141.00 \pm 69.46$ \\
\hline & 24 hours & $166.00 \pm 98.99$ & $159.00 \pm 73.24$ \\
\hline & 72 hours & $201.00 \pm 93.44$ & $187.00 \pm 79.90$ \\
\hline & $5^{\text {th }}$ day & $254.00 \pm 87.72$ & $226.00 \pm 80.84$ \\
\hline \multirow{4}{*}{$\begin{array}{c}\mathrm{SpO}_{2} \\
(\%)\end{array}$} & Baseline & $97.00 \pm 1.76$ & $97.00 \pm 1.67$ \\
\hline & 24 hours & $97.00 \pm 1.52$ & $97.00 \pm 1.47$ \\
\hline & 72 hours & $97.00 \pm 1.48$ & $98.00 \pm 1.03$ \\
\hline & $5^{\text {th }}$ day & $98.00 \pm 1.05$ & $98.00 \pm 1.14$ \\
\hline \multirow{4}{*}{$\begin{array}{l}\text { MMRC } \\
\text { Grade }\end{array}$} & Baseline & $4.00 \pm 1.00$ & $4.00 \pm 1.00$ \\
\hline & 24 hours & $4.00 \pm 1.00$ & $4.00 \pm 1.00$ \\
\hline & 72 hours & $4.00 \pm 1.00$ & $3.00 \pm 1.00$ \\
\hline & $5^{\text {th }}$ day & $3.00 \pm 1.00$ & $3.00 \pm 1.00$ \\
\hline \multirow{3}{*}{$\begin{array}{l}\text { SGRQ } \\
\text { Score }\end{array}$} & Baseline & $86.43 \pm 4.75$ & $88.76 \pm 5.35$ \\
\hline & 24 hours & $82.36 \pm 4.81$ & $82.55 \pm 5.35$ \\
\hline & $5^{\text {th }}$ day & $70.80 \pm 7.09$ & $68.95 \pm 6.75$ \\
\hline \multicolumn{4}{|c|}{$\begin{array}{l}\text { Table 2. Characteristics of the Patients During } \\
\text { Hospitalisation }\end{array}$} \\
\hline
\end{tabular}




\begin{tabular}{|c|c|c|c|c|c|c|}
\hline \multirow[b]{2}{*}{ Interval } & \multicolumn{2}{|c|}{ Control Group } & \multicolumn{2}{|c|}{ Study Group } & \multirow[b]{2}{*}{\begin{tabular}{|c|}
$F$ \\
value
\end{tabular}} & \multirow[b]{2}{*}{$\begin{array}{c}p \\
\text { value }\end{array}$} \\
\hline & $\begin{array}{c}\% \\
\text { Predicted } \\
\text { Mean } \pm \\
\text { S.D. }\end{array}$ & $\begin{array}{c}\text { Actual } \\
\text { Mean } \pm \\
\text { S.D. }\end{array}$ & $\begin{array}{c}\% \\
\text { Predicted } \\
\text { Mean } \pm \\
\text { S.D. }\end{array}$ & $\begin{array}{c}\text { Actual } \\
\text { Mean } \pm \\
\text { S.D. }\end{array}$ & & \\
\hline Baseline & $\begin{array}{c}27.48 \pm \\
10.51\end{array}$ & & $\begin{array}{c}50.57 \pm \\
7.98\end{array}$ & 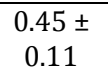 & .11 & 0.25 \\
\hline $\begin{array}{c}24 \\
\text { Hours }\end{array}$ & $\begin{array}{c}29.86 \pm \\
11.26\end{array}$ & $\begin{array}{r}0.5 \\
0.1\end{array}$ & $\begin{array}{c}30.22 \pm \\
9.88\end{array}$ & $\begin{array}{c}0.53 \pm \\
0.15\end{array}$ & 1.21 & 0.94 \\
\hline $\begin{array}{c}72 \\
\text { Hours }\end{array}$ & $\begin{array}{c}37.24 \pm \\
12.26\end{array}$ & $\begin{array}{c}0.69 \pm \\
0.15\end{array}$ & $\begin{array}{c}36.63 \pm \\
11.82\end{array}$ & $\begin{array}{c}0.64 \pm \\
0.17\end{array}$ & 1.08 & 0.74 \\
\hline $5^{\text {th }} \mathrm{D}$ & $\begin{array}{c}47.19 \pm \\
13.92\end{array}$ & $\begin{array}{c}0.80 \pm \\
0.16\end{array}$ & $\begin{array}{c}46.63 \pm \\
14.40\end{array}$ & $\begin{array}{c}0.82 \pm \\
0.19\end{array}$ & 1.00 & \\
\hline
\end{tabular}

Table 3. Comparison of Forced Expiratory Volume in One Second (FEV $)_{1}$ at Different Intervals

\begin{tabular}{|c|c|c|c|c|c|c|}
\hline \multirow{3}{*}{ Interval } & \multicolumn{2}{|c|}{ Control Group } & \multicolumn{2}{|c|}{ Study Group } & \multirow{3}{*}{\begin{tabular}{|c|}
$F$ \\
value
\end{tabular}} & \multirow{3}{*}{$\begin{array}{c}p \\
\text { value }\end{array}$} \\
\hline & \begin{tabular}{|c|}
$\%$ \\
Predicted \\
\end{tabular} & Actual & \begin{tabular}{|c|}
$\%$ \\
Predicted
\end{tabular} & Actual & & \\
\hline & \begin{tabular}{|c|} 
Mean \pm \\
S.D.
\end{tabular} & $\begin{array}{l}\text { Mean } \pm \\
\text { S.D. }\end{array}$ & $\begin{array}{c}\text { Mean } \pm \\
\text { S.D. }\end{array}$ & $\begin{array}{c}\text { Mean } \pm \\
\text { S.D. }\end{array}$ & & \\
\hline Baseline & $\begin{array}{c}40.00 \\
\pm 13.82 \\
\end{array}$ & $\begin{array}{c}0.99 \pm \\
0.33\end{array}$ & $\begin{array}{c}37.79 \pm \\
8.56\end{array}$ & $\begin{array}{c}0.88 \pm \\
0.14\end{array}$ & 1.33 & 0.150 \\
\hline $\begin{array}{c}24 \\
\text { Hours }\end{array}$ & $\begin{array}{c}42.94 \pm \\
14.43\end{array}$ & $\begin{array}{c}1.06 \pm \\
0.31\end{array}$ & $\begin{array}{c}42.67 \pm \\
10.37\end{array}$ & $\begin{array}{c}0.99 \pm \\
0.18\end{array}$ & 1.06 & 0.650 \\
\hline $\begin{array}{c}72 \\
\text { Hours } \\
\end{array}$ & $\begin{array}{c}50.35 \pm \\
16.17 \\
\end{array}$ & $\begin{array}{c}1.24 \pm \\
0.33 \\
\end{array}$ & $\begin{array}{c}48.35 \pm \\
12.08 \\
\end{array}$ & $\begin{array}{c}1.13 \pm \\
0.22 \\
\end{array}$ & 1.23 & 0.415 \\
\hline $5^{\text {th }}$ Day & $\begin{array}{c}58.68 \pm \\
18.89\end{array}$ & $\begin{array}{c}1.45 \pm \\
0.37\end{array}$ & $\begin{array}{c}58.09 \pm \\
15.16\end{array}$ & $\begin{array}{c}1.36 \pm \\
0.26\end{array}$ & 2.01 & 0.803 \\
\hline
\end{tabular}

\begin{tabular}{|c|c|c|}
\hline \multirow{2}{*}{ Intervals } & Control Group (n=62) & Study Group (n = 63) \\
\cline { 2 - 3 } & Mean \pm SD & Mean \pm SD \\
\hline Baseline & $4 \pm 0$ & $4 \pm 0$ \\
\hline 24 Hours & $4 \pm 0$ & $4 \pm 0$ \\
\hline 72 Hours & $4 \pm 0$ & $3 \pm 0$ \\
\hline 5th Day & $3 \pm 0$ & $3 \pm 0$ \\
\hline \multicolumn{2}{|c|}{ Table 5. Comparison of MMRC Grading } \\
at Different Intervals \\
\hline
\end{tabular}

\begin{tabular}{|c|c|c|c|c|c|}
\hline \multirow[t]{2}{*}{ Intervals } & \multicolumn{2}{|c|}{$\begin{array}{l}\text { Control Group } \\
(n=62)\end{array}$} & \multicolumn{2}{|c|}{$\begin{array}{l}\text { Study Group } \\
\quad(n=63)\end{array}$} & \multirow[t]{2}{*}{ p value } \\
\hline & \multicolumn{2}{|c|}{ Mean \pm S.D. } & \multicolumn{2}{|c|}{ Mean \pm S.D. } & \\
\hline Baseline & \multicolumn{2}{|c|}{$86.43 \pm 4.75$} & \multicolumn{2}{|c|}{$88.76 \pm 5.32$} & 0.377 \\
\hline 24 hours & \multicolumn{2}{|c|}{$82.36 \pm 4.81$} & \multicolumn{2}{|c|}{$82.55 \pm 5.35$} & 0.164 \\
\hline $5^{\text {th }}$ day & \multicolumn{2}{|c|}{$70.80 \pm 7.09$} & \multicolumn{2}{|c|}{$68.95 \pm 6.75$} & 0.013 \\
\hline \multicolumn{6}{|c|}{$\begin{array}{l}\text { Improvement in SGRQ score } \\
\text { umber of patients and percentage) }\end{array}$} \\
\hline Improved & 50 & $83.34 \%$ & 58 & $89.30 \%$ & \\
\hline Same & 08 & $13.33 \%$ & 07 & $10.70 \%$ & \\
\hline Worsen & 02 & $3.33 \%$ & - & - & \\
\hline \multicolumn{6}{|c|}{$\begin{array}{l}\text { Table 6. St. George Respiratory Questionnaire } \\
\text { (SGRQ) Score }\end{array}$} \\
\hline
\end{tabular}

\begin{tabular}{|c|c|c|c|c|}
\hline \multirow{2}{*}{ Duration } & \multicolumn{2}{|c|}{$\begin{array}{c}\text { Control Group } \\
\text { (n=62) }\end{array}$} & \multicolumn{2}{c|}{$\begin{array}{c}\text { Study Group } \\
\text { (n=63) }\end{array}$} \\
\cline { 2 - 5 } & No. & Percentage & No. & Percentage \\
\hline 5 days & 13 & $21.7 \%$ & 25 & $38.4 \%$ \\
\hline 6 to 10 days & 35 & $58.3 \%$ & 33 & $50.8 \%$ \\
\hline$>10$ days & 12 & $20.0 \%$ & 07 & $10.8 \%$ \\
\hline Total & 60 & $100 \%$ & 65 & $100 \%$ \\
\hline \multicolumn{2}{|c|}{ Table 7. Duration of Hospitalisation (Days) } \\
\hline
\end{tabular}

\section{DISCUSSION}

A total of 125 patients were included into the study. Sixtythree patients were in the study group and another sixty-two patients were in control group. In the study by Morice et al, 7 the mean baseline $\mathrm{FEV}_{1}$ was similar in both groups $(1.8 \mathrm{~L} / \mathrm{sec}$ and $1.9 \mathrm{~L} / \mathrm{sec}$ for prednisolone and budesonide, respectively). There was no significant difference in response to treatments. In the present study, baseline $\mathrm{FEV}_{1}$ was $0.45 \pm 0.11 \mathrm{~L} / \mathrm{Sec}$ in study group and $0.51 \pm 0.14 \mathrm{~L} / \mathrm{Sec}$ in control group. In the study group, mean improvement in $\mathrm{FEV}_{1}$ after 24 hours, 72 hours and at $5^{\text {th }}$ day were $0.53 \pm 0.15 \mathrm{~L} / \mathrm{Sec}, 0.64 \pm 0.18 \mathrm{~L} / \mathrm{Sec}$ and $0.82 \pm 0.19 \mathrm{~L} / \mathrm{Sec}$ respectively while in the control group the mean improvement in $\mathrm{FEV}_{1}$ was $0.55 \pm 0.15 \mathrm{~L} / \mathrm{Sec}, 0.69 \pm$ $0.15 \mathrm{~L} / \mathrm{Sec}$ and $0.80 \pm 0.16 \mathrm{~L} / \mathrm{Sec}$ respectively. It was observed that there was no statistical significance observed in $\mathrm{FEV}_{1}$ improvement between the two groups. Similar results were observed by Matais et al, 8 Gunen et $\mathrm{al}^{9}$ and Wei et al. ${ }^{10}$ In a study by Gunen et $\mathrm{al}^{9}$ when comparison was made between groups treated with placebo, systemic steroids and nebulised budesonide, the baseline FVC was $64.5 \pm 21.5$ L/Sec, $57.5 \pm 17.5 \mathrm{~L} / \mathrm{Sec}$ and $64.3 \pm 20.4 \mathrm{~L} / \mathrm{Sec}$ in group 1 , group 2 and group 3 respectively. Improvement observed in FVC at 24 hours, 72 hours, 7 days and at $10^{\text {th }}$ day was significantly higher in group 2 and group 3 when compared to group 1. There was no statistical significance as comparison was made between group 2 and group 3 . In the present study, the baseline FVC observed in study and control group was $0.88 \pm 0.19 \mathrm{~L} / \mathrm{Sec}$ and $0.99 \pm 0.30 \mathrm{~L} / \mathrm{Sec}$ respectively. FVC improvement observed after 24 hours, 72 hours and at $5^{\text {th }}$ day in study group was $0.99 \pm 0.18 \mathrm{~L} / \mathrm{Sec}, 1.13 \pm 0.22 \mathrm{~L} / \mathrm{Sec}$ and $1.36 \pm 0.26 \mathrm{~L} / \mathrm{Sec}$ respectively. FVC improvement in control group was $1.06 \pm 0.31,1.24 \pm 0.33 \& 1.45 \pm 0.37$ $\mathrm{L} / \mathrm{Sec}$ respectively. The results of the present study were similar to those observed by Gunnen et $\mathrm{al}^{9}$ and Morris et al. ${ }^{7}$ In a study by Mirici et al,11 the improvement in PEFR at different intervals in both parenteral steroid and nebulised budesonide group were similar and it was observed that there was no statistical difference between two groups. In the present study, baseline PEFR in both study and control groups were $141 \pm 69.46 \mathrm{~L} / \mathrm{M}$ and $139 \pm 91.15 \mathrm{~L} / \mathrm{M}$ respectively. Similarly, no statistical difference was observed among the two groups.

In the present study, the MMRC grades of dyspnoea at baseline, 24 hours, 72 hours and at 5 th day were $4,4,3$, and 3 in study group; while it was 4, 4, 4 and 3 in control group respectively. Compared to control group there were early improvements in severity of dyspnoea in study group. But statistically this was negligible. Similar improvement in the dyspnoea index has been observed by Morrice et al $^{7}$ and Wei et al. ${ }^{9}$ Maltais et el ${ }^{12}$ observed reduction in Borg Dyspnoea Scale between the nebulised budesonide group and the control group. In the present study, the baseline SGRQ score observed in study and control group were $88.76 \pm 5.32$ and $86.43 \pm 4.75$ respectively. SGRQ score improvement after 24 hours and at $5^{\text {th }}$ day in study group was $82.55 \pm 5.35$ and $68.95 \pm 6.75$ while it was $82.36 \pm 4.81$ and $70.80 \pm 7.09$ in control group. Patients in study group showed better improvement in HQRL score as compared to control group. Mirici et al $^{11}$ also observed similar improvement in SGRQ score after nebulised budesonide in AECOPD patients. 
In the study by Gunen et $\mathrm{al}^{8}{ }^{8}$ proportions of the patients with early (relatively) and delayed discharges did not yield any statistically significant results, between the control and study groups. In the present study, mean duration of hospitalisation was $7 \pm 2.9$ days in study group while in control group it was $7.25 \pm 2.8$ days. More number of patients discharged early in study group as compared to control group. The overall reduction in duration of hospitalisation was similar as those observed by Maltais et al ${ }^{12}$ and Guozhong et al.10 In the present study, deterioration of AECOPD while patients under study was defined as the need for treatment intensification according to the treating doctor, the development of confusion, lethargy, acute respiratory acidosis or necessity for mechanical ventilator assistance. One patient each in the study and control group deteriorated and they required mechanical ventilation. Maltais et al ${ }^{12}$ and Wei et al $^{9}$ observed that budesonide group had less systemic side effects than the groups treated with systemic steroids. In the present study, the side effect profile of nebulised budesonide was excellent. No patient had any side effect due to nebulised budesonide including oral candidiasis. Thus, there was no discontinuation of the patients in the study group due to side effects. Marcus et al ${ }^{13}$ also observed that inhaled budesonide was well tolerated in AECOPD.

Gunen et $\mathrm{al}^{8}$ showed exacerbation rates within one month of discharge were 14, eight and nine in placebo, parenteral and nebulised budesonide groups respectively. In the present study, it was observed that two patients in study group and 5 patients in control group had relapse of AECOPD. Marcus et al ${ }^{13}$ showed there was $70 \%$ reduction in relapse of AECOPD over a period of one year.

\section{CONCLUSION}

In conclusion, with the nebulised budesonide for the AECOPD, there was not much improvement in the lung functions, but there was improvement in the quality of life and the duration of hospitalisation in the study group.

\section{REFERENCES}

[1] Celli BR, MacNee W, ATS/ERS Task Force. Standards for the diagnosis and treatment of patients with COPD: a summary of the ATS/ERS position paper. Eur Respir J 2004;23(6):932-46.

[2] Global initiative for chronic obstructive lung disease. National Institutes of Health, National Heart, Lung and Blood Institute. Revised 2017. http://goldcopd.com 5.07.2017.
[3] McEvoy CE, Ensrud KE, Bender E, et al. Association between corticosteroid use and vertebral fractures in older men with chronic obstructive pulmonary disease. Am J Respir Crit Care Med 1998;157(3 Pt 1):704-9.

[4] Henzen C, Suter A, Lerch E, et al. Suppression and recovery of adrenal response after short-term, highdose glucocorticoid treatment. Lancet 2000;355(9203):542-5.

[5] Johansson SA, Andersson KE, Brattsand R, et al. Topical and systemic glucocorticoid potencies of budesonide, beclomethasone dipropionate and prednisolone in man. Eur J Respir Dis Suppl 1982;122:74-82.

[6] Mitchell CE, Alpers JH, Morton SM, et al. Comparison of nebulized budesonide with oral prednisolone in the treatment of severe acute asthma (abstract). Eur Respir J 1995;8:S490.

[7] Morice AH, Morris D, Lawson-Matthew P. A comparison of nebulized budesonide with oral prednisolone in the treatment of exacerbations of obstructive pulmonary disease. Clin Pharmacol Ther 1996;60(6):675-8.

[8] Gunen H, Hacievliyagil SS, Yetkin O, et al. The role of nebulised budesonide in the treatment of acute exacerbations of COPD. Eur Respir J 2007;30:399-400.

[9] Wei H, Xin Z. Nebulised budesonide in the treatment of acute exacerbations of chronic obstructive pulmonary disease. Practical Clinical Medicine Magazine 2004:2. http://scholar.ilib.cn/A-jslcyxzz200402003. html 5.7.2017.

[10] Guozhong C, Wen X, Qi Z, et al. The effect of inhaled Budesonide in persons with acute exacerbations of chronic obstructive pulmonary disease. Chinese General Medicine 2005:20. http://scholar.ilib.cn/Azgqkyx 200520011. html 5.7.2017.

[11] Mirici A, Meral M, Akgun M. Comparison of the efficacy of nebulised budesonide with parenteral corticosteroids in the treatment of acute exacerbations of chronic obstructive pulmonary disease. Clin Drug Invest 2003;23(1):55-62.

[12] Maltais F, Ostinelli J, Bourbeau J, et al. Comparison of nebulized budesonide and oral prednisolone with placebo in the treatment of acute exacerbations of chronic obstructive pulmonary disease: a randomised controlled trial. Am J Respir Crit Care Med 2002;165(5):698-703.

[13] Marcus P. Budesonide Inhalation Suspension in adults with poorly controlled asthma or chronic obstructive pulmonary disease. J Appl Res 2009;9(1 \& 2):2-13. 